\title{
Erratum to: Correlates of victimisation amongst people with psychosis
}

\author{
Benjamin Chapple ${ }^{1} \cdot$ David Chant $^{1} \cdot$ Patricia Nolan $^{1} \cdot$ Sue Cardy $^{1}$. \\ Harvey Whiteford ${ }^{1} \cdot$ John McGrath $^{1}$
}

Published online: 12 January 2016

(c) Springer-Verlag Berlin Heidelberg 2016

\section{Erratum to: Soc Psychiatry Psychiatr Epidemiol (2004) 39:836-840 \\ DOI 10.1007/s00127-004-0819-4}

We have recently been alerted to errors in Table 1 of this publication. We have re-analysed the primary data and provided a corrected and expanded version of Table 1 . We wish to draw attention to the findings that demonstrate a significant association between being a victim of violent crime and the following socio-demographic and clinical variables; (a) younger age, (b) homeless status in the last 12 months, (c) substance abuse or dependence, (d) being arrested in the last 12 months, (e) impaired social and occupational functioning. Neither sex nor chronic course of disorder were significantly associated with victim status. We apologize for errors in the original publication, and request that readers take the corrections into account when reading the original publication.
The online version of the original article can be found under doi:10.1007/s00127-004-0819-4.

\section{John McGrath}

john_mcgrath@qcsr.uq.edu.au

1 Queensland Centre for Mental Health Research, The Park Centre for Mental Health, Wacol, (QLD) 4076, Australia 
Table 1 Number of subjects who were victims of violence in the last 12 months, by risk factors

\begin{tabular}{|c|c|c|c|c|c|}
\hline \multirow[t]{2}{*}{ Risk factor } & \multirow[t]{2}{*}{ Levels $^{\mathrm{a}}$} & \multicolumn{2}{|c|}{$\begin{array}{l}\text { Victims of violence in last } \\
12 \text { months }\end{array}$} & \multirow{2}{*}{$\begin{array}{l}\text { Model } 1 \\
\text { OR }(95 \% \mathrm{CI})\end{array}$} & \multirow{2}{*}{$\begin{array}{l}\text { Model } 2 \\
\text { OR }(95 \% \mathrm{CI})\end{array}$} \\
\hline & & Yes & No & & \\
\hline \multirow[t]{2}{*}{ Age } & 39 years and below & 103 & 399 & \multirow[t]{2}{*}{$1.63 *(1.15,2.29)$} & \multirow[t]{2}{*}{$1.62 *(1.14,2.28)$} \\
\hline & 40 years and over & 63 & 397 & & \\
\hline \multirow[t]{2}{*}{ Sex } & Female & 63 & 324 & \multirow[t]{2}{*}{$0.89(0.63,1.26)$} & \multirow[t]{2}{*}{$0.95(0.67,1.35)$} \\
\hline & Male & 103 & 472 & & \\
\hline \multirow[t]{2}{*}{ Homeless in the last 12 months } & Yes & 40 & 66 & \multirow[t]{2}{*}{$3.51 *(2.27,5.43)$} & \multirow[t]{2}{*}{$3.46 *(2.22,5.39)$} \\
\hline & No & 126 & 730 & & \\
\hline \multirow[t]{2}{*}{ Substance abuse and dependence } & Yes & 91 & 308 & \multirow[t]{2}{*}{$1.92 *(1.37,2.69)$} & \multirow[t]{2}{*}{$1.84 *(1.29,2.64)$} \\
\hline & No & 75 & 488 & & \\
\hline \multirow[t]{2}{*}{ Arrested in the last 12 months } & 1 and more times & 40 & 60 & \multirow[t]{2}{*}{$3.89 *(2.50,6.06)$} & \multirow[t]{2}{*}{$3.68 *(2.32,5.82)$} \\
\hline & 0 times & 126 & 736 & & \\
\hline \multirow[t]{2}{*}{ Impaired social and occupational functioning ${ }^{\mathrm{b}}$} & Yes & 146 & 584 & \multirow[t]{2}{*}{$2.65 *(1.62,4.34)$} & \multirow[t]{2}{*}{$2.73 *(1.65,4.50)$} \\
\hline & No & 20 & 212 & & \\
\hline \multirow[t]{2}{*}{ Chronic course of disorder } & Yes & 76 & 336 & \multirow[t]{2}{*}{$1.16(0.83,1.62)$} & \multirow[t]{2}{*}{$1.26(0.89,1.78)$} \\
\hline & No & 90 & 460 & & \\
\hline
\end{tabular}

Model 1 unadjusted, Model 2 adjusted for age and sex, OR odds ratio, 95\% CI 95\% confidence interval

* Significant findings shown in bold $(p<0.01)$

${ }^{\text {a }}$ Reference level in italics

b Impaired social and occupational functioning (SOFAS) based on dichotomised cut point greater than and equal to 70 score with 'slight or no impairment' and less than 70 score with 'poor functioning' 